\title{
RAZVOJ POJMA IN KONCEPTA CIVILNO- VOJAŠKEGA SODELOVANJA IN USKLAJEVANJA V MIROVNIH OPERACIJAH
}

\section{DEVELOPMENT OF THE TERM AND THE CONCEPT OF CIVIL-MILITARY CO-OPERATION AND CO- ORDINATION IN PEACE OPERATIONS}

Povzetek Civilno-vojaško sodelovanje (Civil-military co-operation - CIMIC) je v sodobnih mirovnih operacijah pomemben del aktivnosti. Koncept se je razvil iz potrebe po medsebojnem sodelovanju civilnih in vojaških akterjev in je na začetku deloval kot kolektivni termin. Nanašal se je na vse vrste interakcij in stikov med civilnimi organizacijami ter vojsko. Toda povečevanje stopnje interakcije med akterji in rast pomena civilno-vojaškega sodelovanja sta prinesla s seboj razvoj različnih konceptov pod istim izrazom in kratico CIMIC (slov. CVS), kar je vodilo v zmedo in nesporazume. Prispevek predstavlja razvoj koncepta ter značilnosti razvoja konceptov civilno-vojaškega sodelovanja različnih akterjev mirovnih operacij, kot so Nato, Organizacija združenih narodov in njene agencije, Evropska unija ter nekatere humanitarne organizacije. Njegov namen je prispevati k razumevanju različnosti konceptov civilno-vojaškega sodelovanja in s tem k manjšanju možnosti morebitnih sporov med akterji mirovnih operacij.

Ključne besede

Abstract

\section{Civilno-vojaško sodelovanje, CIMIC, CVS, civilno-vojaško usklajevanje.}

In modern peace operations, civil-military cooperation (CIMIC) constitutes an important part of activities. The concept has developed from the need for mutual cooperation of civil and military actors and was initially used as a collective term referring to all types of interaction and relations between civil organizations and the military. However, the increased level of interaction between the actors, and the growing importance of civil-military cooperation have brought along the development of different concepts under the same term and acronym CIMIC, which has resulted in confusion and misunderstanding. The article presents the development of the concept and the characteristics of concept development in civil-military cooperation by different actors of peace operations, such as NATO, the United Nations Organization and its agencies, the European Union and some humanitarian organizations. 
Its aim is to develop the understanding of different civil-military cooperation concepts and consequently reduce the possibility of disputes between peace operations actors.

\section{Key words Civil-military cooperation, CIMIC, civil-military coordination.}

Uvod Sodobne mirovne operacije, ki po definiciji Ramsbothama in Woodhousa (1999, str. xix) vključujejo operacije ohranjanja ali vsiljevanja miru in druge vojaške operacije $\mathrm{v}$ kontekstu političnih in diplomatskih prizadevanj za ustanovitev ter ohranjanje miru, označujeta izrazita večdimenzionalnost in težnja po vse bolj integriranem delovanju vojaških in različnih civilnih akterjev. Zaradi različnih mandatov, narave delovanja in organizacijske kulture ter še drugih razlik med vojaškimi silami in civilnimi akterji v mirovnih operacijah je sodelovanje med njimi polno najrazličnejših dilem, izzivov, težav, kar se kaže že na pojmovni ravni. Kot ugotavlja Rehse $(2004,24)$, je vse od začetka 90. let prejšnjega stoletja civilnovojaško sodelovanje (Civil-Military Cooperation) oziroma njegova kratica CIMIC (v Sloveniji se uveljavlja kratica CVS) kontroverzen termin v vroči razpravi v civilni, humanitarni in vojaški skupnosti, kadar je šlo za njihove medsebojne odnose. V tem času se je termin razvijal od kolektivnega termina za vsakršne civilno-vojaške interakcije in stike, pogosto za menedžment civilno-vojaške prepletenosti (zlasti še med vojsko in humanitarnimi organizacijami), do termina vojaška doktrina.

Razprava o civilno-vojaškem sodelovanju prinaša kar nekaj težav. V pregledu in analizi tega sodelovanja leta 2004 Rehse ugotavlja, da do takrat še ni bilo splošno sprejete in usklajene definicije tega termina. Različni akterji govorijo o civilnovojaškem sodelovanju v različnih kontekstih, z različnimi pomeni in različnimi interpretacijami. Na začetku je civilno-vojaško sodelovanje sicer delovalo kot kolektivni pojem in se je nanašalo na vse vrste interakcij ter stikov med civilnimi organizacijami in vojsko. Oboji so ga jemali kot oznako svojih akcij do druge strani. Toda povečevanje stopnje interakcije med akterji in rast pomena civilno-vojaškega sodelovanja sta s seboj prinesla različne koncepte, ki jih je združeval enak izraz (CIMIC), kar je vodilo v zmedo in nesporazume. Mednarodna skupnost je zato uvedla bolj raznolike pristope $\mathrm{k}$ terminu. Med pomembnejšimi dejavniki tega procesa je bilo povečano sodelovanje Nata v mirovnih operacijah. Delovanje te zveze na Balkanu je povečalo potrebo po nekakšni politiki civilno-vojaškega sodelovanja oziroma doktrini Nata. Nato je tako razvil procedure in vojaško doktrino, po katerih je civilno-vojaško sodelovanje postalo v vojaškem besednjaku dobro opredeljen in specifičen pojem, s tem pa je Nato izraz (mislimo še posebej na kratico CIMIC) pravzaprav prevzel in ga navezal na svoje razumevanje tega sodelovanja. Posledično so druge organizacije za svoje koncepte civilno-vojaškega sodelovanja, da bi jih ločile od Natovega, morale začeti razvijati nove pojme. Tako je na primer Urad Združenih narodov za usklajevanje humanitarnih zadev (United Nations Office for Coordination of Humanitarian Affairs - UNOCHA) za svoje programe, ki so pred letom 2001 potekali pod oznako CIMIC, predstavil okrajšavo UN CMCoorD (Rehse, 2004, str. 15-16). CIMIC moramo sicer še vedno razumeti tudi v širšem oziroma 
splošnem pomenu, torej kot vsake vrste interakcijo med civilnimi in vojaškimi subjekti, hkrati pa se zavedati, da je tudi izraz Natovih politike in doktrine civilnovojaškega sodelovanja. Ob uporabi izraza pa je seveda nujno, da ločimo oboje in poudarimo, na katero razumevanje se izraz CIMIC nanaša (po Rehse, 2004, str. 16).

Prispevek je v osnovni obliki nastal v projektu Vloga države pri vključevanju civilnih subjektov v mednarodne operacije na kriznih območjih, ki je v letih 2007-2008 potekal v okviru Ciljnega raziskovalnega programa Znanost za varnost in mir 20062010, v pripravi za objavo v reviji Sodobni vojaški izzivi pa je bil dopolnjen in posodobljen. ${ }^{1}$ Namenjen je predstavitvi nastanka pojma in prakse civilno-vojaškega sodelovanja ter smeri razvoja njegovega koncepta pri različnih organizacijah. S tem želimo prispevati ne samo $\mathrm{k}$ razumevanju naslovnega pojma, temveč tudi $\mathrm{k}$ razumevanju razlik oziroma posebnosti civilno-vojaškega sodelovanja v mirovnih operacijah pri različnih organizacijah.

\section{NATO IN CIMIC}

Za razvoj Natove doktrine civilno-vojaškega sodelovanja sta bistvenega pomena misiji Iforja in Sforja v Bosni in Hercegovini. Z delovanjem Iforja, ki je imel nalogo uveljaviti vojaške vidike daytonskega mirovnega sporazuma, je bila približno $\mathrm{v}$ letu dni dosežena takšna stopnja varnosti v okolju, da so se lahko začeli uveljavljati civilni vidiki sporazuma in so lahko začele delo nevojaške organizacije. Ifor se je v tem času aktivno vključeval v humanitarno podporo, volitve, dolgoročne projekte in rekonstrukcijo infrastrukture (po Rehse, 2004, str. 27). Kot primer sodelovanja vojske in civilnih organizacij lahko navedemo tudi sodelovanje Sforja in Urada Visokega komisarja Združenih narodov za begunce (UNHCR). Častniki za zvezo in vojaški svetovalci so bili skupaj $\mathrm{v}$ pisarnah tako na regionalnih kot lokalnih ravneh. Vzrok tega sodelovanja je v pomenu, ki ga je UNHCR pripisoval varnosti pri svojih aktivnostih, zlasti pri podpori vračanju beguncev in razseljenih oseb. Mandat Sforja je ne nazadnje vključeval tudi sodelovanje pri uveljavljanju civilnih vidikov mirovnega sporazuma (Studer, 2001, str. 377). Mednarodno delovanje v Bosni in Hercegovini po letu 1995 je torej nekakšna zibelka Natovega civilno-vojaškega sodelovanja.

Razvoj Natovega civilno-vojaškega sodelovanja lahko na kratko pogledamo z analizo, ki jo je opravila Logar Kelc. Ifor je v Bosni in Hercegovini s svojim delovanjem do leta 1996 vzpostavil varno okolje. »To je bilo bistveno za implementacijo civilnih aspektov mirovnega dogovora. Nevojaške organizacije so lahko začele $\mathrm{z}$ delom. Istočasno pa se je Ifor vedno bolj vključeval v humanitarno podporo, volitve na državni ravni, dolgoročne projekte in rekonstrukcijo infrastrukture.« Ta preobrat $\mathrm{v}$ nalogah Iforja je pokazal potrebo po doktrini o civilno-vojaškem sodelovanju kot tudi po posebnih silah, ki bi bile v pomoč Natovim poveljnikom v operacijah v podporo miru. Kmalu po začetku misije Ifor

1 Avtorica se zahvaljuje recenzentom za koristne strokovne napotke. 
je bil v poveljstvu SHAPE ${ }^{2}$ ustanovljen oddelek za civilno-vojaško sodelovanje. Ta je bil odgovoren za zahteve urjenja in pripravo učnih načrtov. Leta 1997 je Vojaški odbor sestavil dokument MC-411 Nato CIMIC. V začetku leta 1998 pa je SHAPE razvil direktivo CIMIC 2000, ki je od tedaj predstavljala podlago za vse nadaljnje načrte in izvedbe.

Kadrovska struktura sil za civilno-vojaško sodelovanje (Civil-Military Task ForceCMTF) je bila še en dejavnik, ki je prispeval $k$ razvoju Natove doktrine o civilnovojaškem sodelovanju. CMTF so bile oblikovane za podporo IFOR-ju in SFOR-ju v Bosni in Hercegovini, večino osebja pa so prispevale Združene države Amerike. Ker pa so hotele biti evropske članice bolj vključene v'novi' Nato, je bilo to neravnovesje treba odpraviti. Cilj je bil 50-odstotna udeležba drugih članic poleg ZDA. Vendar pa je evropskim članicam primanjkovalo usposobljenega osebja, zato je poveljstvo SHAPE začelo izvajati usposabljanje za civilno-vojaško sodelovanje in kmalu se je CMTF prestrukturiral v CIMIC Task Force (CIMIC TF), v katerem so imeli Evropejci znatno večji delež osebja. Strateški koncept iz leta 1999 se eksplicitno nanaša na civilno-vojaško sodelovanje in poudarja pomen le-tega za uspešno dokončanje vojaške operacije - interakcija med zavezniškimi silami in civilnim okoljem (tako vladnim kot nevladnim), v katerem delujejo, je ključna za uspeh operacije. Civilnovojaško sodelovanje je $v$ medsebojni odvisnosti: vojaška sredstva so vedno bolj namenjena le za podporo civilnim oblastem, hkrati pa je civilna podpora vojaški operaciji pomembna za logistiko, komunikacijo, medicinsko oskrbo in javne zadeve. Sodelovanje med zavezniškimi vojaškimi in civilnimi telesi bo zato ostalo bistvenega pomena (Logar Kelc, 2007, str. 20-22).

Izkušnje iz Bosne in Hercegovine torej kažejo, kot ugotavlja Zandee (1999), da se je žarišče civilno-vojaškega sodelovanja po koncu hladne vojne premaknilo z načrtovanja civilne podpore za vojaške operacije na zagotavljanje vojaške podpore za civilne operacije graditve miru. Avtor tudi pravi, da:

/.../ vloge CIMIC-a ne smemo ne precenjevati in ne podcenjevati. Prvič, CIMIC ne nadomešča civilne implementacije, ampak podpira civilne napore. Ima pa vendarle bistveno vlogo pri zapolnjevanju praznega prostora, dokler strani in civilne organizacije niso v položaju, ko lahko same peljejo naprej mirovni proces. Drugič, CIMIC predstavlja veliko več kot le preprosto gradnjo šol in bolnišnic ter lokalnih skupnosti, čeprav so to, jasno, pomembne dejavnosti in prispevajo $k$ nastajanju lokalne podpore vojaškim enotam. CIMIC ima ključno vlogo v skoraj vsakem vidiku civilne implementacije, pa bodisi gre za vračanje beguncev in razseljenih oseb, ponovno vzpostavljanje reda in miru, ekonomsko rekonstrukcijo, obnovo infrastrukture, organiziranje volitev ali ustanavljanje novih institucij. Je cement, ki drži skupaj zidake za mir. In še, ko se postavijo prihodnje zahteve za CIMIC, ne smemo upoštevati le izkušenj iz IFOR-ja oziroma SFOR-ja. Vsak konflikt ima namreč specifičen kontekst in mirovni sporazumi so narejeni od primera do primera. Ne

2 SHAPE - Supreme Headquarters Allied Powers Europe. Vrhovno poveljstvo sil zavezništva v Evropi. 
glede na to pa je treba $v$ vsaki pokonfliktni mirovni operaciji izvajati vrsto podobnih dejavnosti s podporo vojske. Obstaja jasna potreba po skupnih načrtih glede CIMIC-a in njegove strukture, toda vse mora biti fleksibilno, da se lahko prilagodi neposrednim razmeram (Zandee, 1999).

Natova definicija civilno-vojaškega sodelovanja je: usklajevanje in sodelovanje (koordinacija in kooperacija) v podporo misiji med poveljnikom Nata in civilnimi akterji, vključno $\mathrm{z}$ nacionalnim prebivalstvom in lokalnimi oblastmi ter $\mathrm{z}$ mednarodnimi, nacionalnimi in nevladnimi organizacijami ter agencijami (po AJP-9 2003, AJP-3.4.9. 2013 in po Natovi vojaški politiki o civilno-vojaškem sodelovanjuMilitary Council Doctrine-MC 411/1). Namen in cilj civilno-vojaškega sodelovanja je interakcija med vojaškimi in civilnimi akterji v okolju v podporo načrtom vojaškega poveljnika. V idealnih razmerah bodo vsi akterji delovali za skupen cilj, kadar pa to ne bo mogoče, bo ta interakcija zagotavljala, da bodo vsi načrti usklajeni, kolikor bo pač mogoče. S tem se bodo, kolikor je mogoče, zmanjšali vmešavanje in nehoteni spori med akterji (AJP-3.4.9., str. 2-1). J9 - oddelek za CIMIC - je odgovoren za zagotavljanje celovitih usmeritev ter usklajevanje in svetovanje Natovemu strateškemu poveljstvu za operacije (Allied Command Operations - ACO) (NATO SHAPE - Civil-Military Cooperation). V organizacijskem smislu moramo omeniti še Večnacionalno skupino za civilno-vojaško sodelovanje, ki je Natova specializirana enota za civilno-vojaško sodelovanje na operativni in taktični ravni, ter Center odličnosti za civilno-vojaško sodelovanje (CCOE), ki ne spada v poveljevalno shemo Nata, ukvarja pa se s svetovanjem, usposabljanjem in izobraževanjem, razvojem doktrin in konceptov ter procesom učenja iz izkušenj (Mazurkiewicz 2014, str. 133; Multinational CIMIC Group; CIMIC Centre of Excellence).

Rehse (2004, str. 30) glede na opredelitev civilno-vojaškega sodelovanja v Natovih dokumentih ugotavlja, da je CIMIC taktična doktrina in ne strategija. Uporablja se kot instrument za dosego ciljev vojaške operacije. Mustonen (2008, str. 21) pravi, da Natova doktrina predstavlja CIMIC predvsem kot orodje poveljnika in taktično doktrino, ne kot strategijo za usklajevanje.

Za CIMIC se označuje tista pomoč, ki je nujna za podporo vojaškim operacijam. Prek verige poveljevanja pa se izvaja le, če pri tem sodeluje primerna organizacija, na primer Organizacija združenih narodov (OZN). Natova politika civilno-vojaškega sodelovanja torej opredeljuje vojaško vključevanje v naloge, ki so nevojaške narave in so običajno pod odgovornostjo mandatne civilne oblasti. Dodatna pomoč, ki ni del vojaškega mandata z vojaško-političnimi cilji, se ne razume kot CIMIC (Rehse, 2004, str. 31-32).

Natova doktrina civilno-vojaškega sodelovanja predvideva civilno-vojaško sodelovanje $\mathrm{v}$ treh stopnjah življenjskega ciklusa operacije. V predoperacijski fazi njegovo osebje pomaga silam pri pripravah na civilne razmere operacije. Med operacijo zagotavlja civilno-vojaško sodelovanje, vzpostavljanje in ohranjanje odnosov s civilnimi telesi za podporo delu poveljnika. V tranzicijskem obdobju 
pa pomaga pri predaji aktivnosti novim oblastem (Rehse, 2004, str. 33). Naloge Natovega CIMIC-a obsegajo tri področja delovanja, in sicer civilno-vojaške zveze ${ }^{3}$ (nujno usklajevanje s civilnimi telesi), podporo civilnemu okolju (interakcija s civilnimi telesi med operacijo) in podporo silam (zadeve, ki zahtevajo civilno podporo vojski) (Rehse, 2004, str. 33-34).

Natova doktrina civilno-vojaškega sodelovanja v splošnem poudarja, da se zavezništvo ukvarja izključno z nalogami, ki so povezane z varnostjo. Če je treba in če je skladno z operativnim načrtom ter mandatom civilnih oblasti, se lahko podprejo tudi civilne naloge, ki jih izvaja primerna civilna avtoriteta (nima pa CIMIC nadzora nad civilnimi telesi) ${ }^{4}$ (Rehse, 2004, str. 36, 39). Ne nazadnje je civilno-vojaško sodelovanje tudi del Natovega celovitega pristopa, ki je usmerjen $\mathrm{v}$ doseganje enotnosti cilja in ne toliko enotnosti prizadevanj ali enotnosti poveljevanja (glej Mazurkiewicz, 2014, str. 131).

Kljub novim dokumentom (kot je AJP-3.4.9.) se zdi, da vsebina Natovega civilno-vojaškega sodelovanja ostaja podobna, se je pa področje v zadnjih letih institucionalno razvilo. Že omenjena Večnacionalna skupina za civilno-vojaško sodelovanje (Multinational CIMIC Group - MNCG) ${ }^{5}$ oziroma poveljstvo za CIMIC je bilo v Natu uradno ustanovljeno aprila 2009 (SHAPE News Release, 5. maj 2009). Njegova predhodnica, CIMIC skupina jug, je bila ustanovljena v Motta di Livenza v Italiji že leta 2002 (Mazurkiewicz, 2014, str. 133-134).

\section{ORGANIZACIJA ZDRUŽENIH NARODOV TER CIVILNO-VOJAŠKO SODELOVANJE IN USKLAJEVANJE}

Rehse (2004) v analizi konceptov, definicij in prakse civilno-vojaškega sodelovanja ugotavlja, da se je po letu 1991 začel značaj operacij OZN za ohranjanje miru precej spreminjati. Čeprav je vojska še vedno bistven del mirovnih sil, se povečuje število civilistov, ki delajo skupaj z vojaki. Operacije so namreč postale celovitejše, OZN uporablja termin večdimenzionalne mirovne operacije, ki vključujejo poleg vojaških še vrsto humanitarnih vidikov. Drugi razlog je širitev humanitarnega vidika in naraščanja števila različnih agencij (tako agencije OZN kot nevladne) za razdeljevanje pomoči v teh operacijah. Vzrok je tudi v tem, da se je vojska približala

\footnotetext{
Civil-Military Liaison.

${ }_{4}$ Doktrina sicer predvideva nekaj izjemnih okoliščin, v katerih se od vojske lahko zahteva, da prevzame tudi tiste naloge, ki so običajno v odgovornosti civilnih oblasti. Govorimo o okoliščinah, ko neko civilno telo ni prisotno ali pa je nesposobno izpolnjevati svoj mandat ipd. (dokler to civilno telo ni pripravljeno na prevzem nalog), kadar gre za življenjsko ogroženost lokalnega prebivalstva ali za dolgoročno stabilnost družbe (po Rehse, 2004, 37).

Memorandum of Understanding, ki je uvedel civilno-vojaško sodelovanje na ravni poveljstva, so 28. aprila 2009 podpisali predstavniki petih držav članic Nata, in sicer Grčije, Madžarske, Italije, Portugalske in Romunije, ter SHAPE. S tem se je leta 2002 ustanovljena skupina jug (sedež v Motta di Livenza v Italiji), v kateri so sodelovale Grčija, Madžarska, Portugalska in Romunija, leta 2009 pa sta sile poverili tudi Bolgarija in Slovenija, preoblikovala v Večnacionalno skupino za civilno-vojaško sodelovanje (SHAPE News Release, 5. maj 2009).
} 
civilnim vidikom misije, s čimer so se povečali stiki med vojsko in civilnimi akterji, odnosi med njimi pa postajajo vse pomembnejši.

Rehse (2004, str. 13) tudi ugotavlja, da se je po polomih v mirovnih operacijah v Somaliji, Ruandi ter Bosni in Hercegovini (primer Srebrenice) v 90. letih prejšnjega stoletja spremenil odnos članic OZN. Niso bile več pri volji, da bi se z operacijami lotevale bistvenih vzrokov konfliktov, temveč so se nagibale k uporabi mešanice humanitarnih in političnih mandatov - kot nadomestilo vojaških in političnih akcij za končanje konfliktov. ${ }^{6}$

OZN je namesto civilno-vojaškega sodelovanja začela razvijati koncept civilnovojaškega usklajevanja (oziroma civilno-vojaško koordinacijo), Urad ZN za usklajevanje humanitarnih zadev (UN Office for the Coordination of Humanitarian Affairs - OCHA) za označevanje te aktivnosti uporablja kratico CMCoord (CivilMilitary Co-ordination). Za oznako civilno-vojaškega usklajevanja oziroma koordinacije se uporablja tudi kratica CMCO (po Mustonen, 2008, str. 21). V praksi najdemo poleg CIMIC in CMCoord še precej drugih poimenovanj in okrajšav oziroma kratic - CIMCO, CMO, CMA, CML, CMLO ipd. CIMIC povezujemo z Natom, poznajo ga tudi v večini evropskih držav ter v Kanadi, Avstraliji ter na Novi Zelandiji. Evropska unija razvija nov koncept civilno-vojaškega usklajevanja (angl. CIMCO), Združene države Amerike (ZDA) pa imajo svojo doktrino in terminologijo ter uporabljajo termin civilno-vojaške operacije (angl. CMO) (Coning, 2007, str. 4-5).

Coning (2007, str. 5) ugotavlja, da se mirovne operacije OZN razlikujejo od večine mirovnih in stabilizacijskih operacij Nata, Evropske unije ter koalicij, in sicer v dvojem. Prvič, zanje je značilno, da temeljijo na konsenzu - da se vzpostavijo po premirju ali podpisu mirovnega sporazuma na zahtevo strani v konfliktu in za podporo pri uveljavljanju mirovnega sporazuma. In drugič, vojaška sila je le del integriranih mirovnih misij pod celovitim civilnim vodenjem in je torej le nekako vstavljena v misijo OZN. Zato tudi ni potrebe, da se v teh misijah oblikuje poseben mehanizem za civilno-vojaško usklajevanje, saj so odnosi med vojaško in drugimi komponentami misije že določeni v veljavnih politikah $\mathrm{OZN}^{7}$ ter $\mathrm{v}$ mandatu in organizacijski strukturi operacije. ${ }^{8}$ Že v OZN torej obstaja več usklajevalnih mehanizmov za misije nasploh.

\footnotetext{
6 Rehsejevi ugotovitvi o nenaslavljanju vzrokov konflikta je mogoče ugovarjati. Ravno spremenjeni mandati in vidiki operacij (humanitarni in politični mandati) naj bi določali vzroke konfliktov (pogosto so to revščina in druge neenakosti ter slabo delovanje političnih institucij), medtem ko vojaške misije predvsem pomagajo vzpostavljati ali ohranjati varno okolje ali vsaj okolje brez odkritih oboroženih konfliktov.

Na primer: UN Administrative Committee on Coordination (ACC) Guidelines on the Functioning of the Resident Coordination System (24 September 1999); UN Secretary-General's Note of Guidance on Relations between Representatives of the Secretary General, Resident Coordinators and Humanitarian Coordination (11 December 2000); UN Secretary-General's Note of Guidance in Integrated Missions (17 January 2006), in DPKO's Policy Directive on Joint Operations centers and Joint Mission Analysis Centres (31 May 2006) (Coning, 2007, 5 - footnote 6).

8 Vključeni, na primer: Joint Operations Centre (JOC), Joint Mission Analysis Cell (JMAC), Integrated Mission Planning Team (IMPT) ipd. (Coning, 2007, 6).
} 
Uporaba terminov sodelovanje (kooperacija) nasproti usklajevanje (koordinacija) kaže na razlikovanje med Natovimi operacijami, v katerih je tudi na strateški ravni nujno civilno-vojaško sodelovanje, in kontekstom misij OZN, v katerih je vojaška komponenta vstavljena $\mathrm{v}$ misijo in udeležena $\mathrm{v}$ več usklajevalnih mehanizmih v celotni misiji. Z vidika OZN se usklajevanje nanaša na spekter odnosov, ki se vrstijo od koeksistence do kooperacije. Koncept usklajevanja je bil v OZN razvit v kontekstu humanitarnega civilno-vojaškega usklajevanja, v katerem se koeksistenca nanaša na položaj, pri katerem se med humanitarno skupnostjo in vojaško bojno silo deli minimum nujnih informacij. To najpogosteje vključuje delitev informacij o varnosti, premikih humanitarnih konvojev in menedžmentu skupnih virov (npr. pristanišča ali letališča). Sodelovanje se nanaša na maksimalno stanje civilnovojaškega usklajevanja, $\mathrm{v}$ katerem najdemo vrsto sodelovalnih odnosov med humanitarno skupnostjo in vojaško silo, ki pa je ne razumemo kot bojno silo. Ti odnosi vsebujejo skupno načrtovanje, delitev dela in informacij (Coning, 2007, str. 7). Coning ugotavlja, da se zdi, da Nato in OZN razumeta sodelovanje in usklajevanje nasprotno. V Natovem kontekstu je namreč sodelovanje razumljeno kot manj povezovalno v primerjavi z usklajevanjem, Nato tudi trdi, da je humanitarna skupnost pripravljena sodelovati, ne pa se usklajevati.

Vendar so terminologija in koncepti civilno-vojaškega usklajevanja različni že znotraj OZN. Kot ugotavlja Coning (2007, str. 8), najdemo pri OZN sicer dva skladna, čeprav različna pristopa $\mathrm{k}$ civilno-vojaškemu usklajevanju, in sicer humanitarnega in pristop mirovnih operacij. Humanitarni pristop je pristop Urada OZN za usklajevanje humanitarnih zadev, ki je pod vodstvom Medagencijskega stalnega odbora (Inter-Agency Standing Committee - IASC) razvil vrsto politik in smernic za humanitarno civilno-vojaško usklajevanje v OZN. Leta 2004 je bil koncept humanitarnega civilno-vojaškega usklajevanja v OZN s kratico UN CMCoord opredeljen kot bistven dialog in interakcija med civilnimi in vojaškimi akterji v humanitarnih krizah, ki je nujen, da se zaščitijo ter spodbujajo humanitarna načela, da se izognejo tekmovanju, da se minimalizirajo protislovja in se, kadar je treba, teži k skupnim ciljem. Temeljne strategije se vrstijo od koeksistence do sodelovanja. Usklajevanje je skupna odgovornost, ki se krepi s stiki in skupnim usposabljanjem (Coning, 2007, str. 8-10).

Humanitarni pristop poudarja prednost humanitarnih ciljev in delo humanitarnih organizacij, medtem ko naj bi se vojaške zmogljivosti vključevale, kolikor je najmanj mogoče, in znotraj humanitarnih načel ravnanja. ${ }^{9}$

Koncept civilno-vojaškega usklajevanja v kontekstu mirovnih operacij OZN mora pokriti vse mogoče scenarije misij in ustrezati celotnemu življenjskemu ciklu mirovne operacije, torej od stabilizacijske faze, ki se osredotoča na doseganje varnega okolja in zagotavljanje podpore humanitarnim akcijam, prek faze tranzicije do faze

\footnotetext{
Na kratko povzetih šest operativnih načel za uporabo vojaških zmogljivosti v humanitarnih operacijah (po Coning, 2007, 9).
} 
konsolidacije, ki je osredotočena predvsem na graditev miru. Oddelek Združenih narodov za operacije ohranjanja miru (Department for Peacekeeping Operations DPKO) je oblikoval posebno definicijo civilno-vojaškega usklajevanja. Sprejeta je bila septembra leta 2002. Glasi se:

Civilno-vojaška koordinacija Združenih narodov je sistem interakcije, ki vključuje izmenjavo informacij, pogajanja, odpravo nasprotij, medsebojno podporo in načrtovanje na vseh ravneh med vojaškimi elementi in humanitarnimi organizacijami, razvojnimi organizacijami in lokalnim civilnim prebivalstvom z namenom, da se dosežejo cilji Združenih narodov (Coning, 2007, str. 8-11).

Novejši dokumenti OZN civilno-vojaško usklajevanje v okviru misij ohranjanja miru, pri čemer uporabljajo kratico UN-CIMIC, opredeljujejo kot vojaško štabno funkcijo v integriranih misijah OZN, ki pospešuje vzajemno delovanje med vojaškimi in civilnimi sestavinami misije ter humanitarnimi razvojnimi akterji na območju misije, da podprejo cilje misije (UN-CM Coord Field Handbook, 2015, str. 77). De Coning in Holshek (2012, 15-17) pa opozarjata tudi, da sta interakciji med vojsko in civilnimi sestavinami misije ter vojsko in humanitarnimi organizacijami le del vloge civilno-vojaškega sodelovanja OZN. V tej vlogi CIMIC OZN deluje kot element za zvezo in deljenje informacij. V svoji drugi vlogi pa skrbi za zagotavljanje podpore pri ustvarjanju okolja, ki bo omogočalo izpolnitev mandata misije. Pri tem deluje posredno, predvsem pa se usmerja $v$ gradnjo lokalnih zmogljivosti in zaupanja.

\section{EVROPSKA UNIJA TER CIVILNO-VOJAŠKO SODELOVANJE IN USKLAJEVANJE}

EU je leta 2002 sprejela koncept o civilno-vojaškem sodelovanju v operacijah kriznega menedžmenta ${ }^{10}$, ki jih vodi (CIMIC Concept for EU-led Crisis Management Operations). Definicija civilno-vojaškega sodelovanja pri EU je: usklajevanje in sodelovanje $\mathrm{v}$ podporo misiji, usklajevanje med vojaškimi sestavinami operacij kriznega menedžmenta EU in civilnimi akterji (zunaj EU), vključno z nacionalnim prebivalstvom in lokalnimi oblastmi, ter mednarodnimi, nacionalnimi in nevladnimi organizacijami in agencijami (po Mustonen, 2008, 21). CIMIC izhaja iz vojaške perspektive, ki jo zanimata zlasti zaščita sil in s tem povezana potreba po sodelovanju z lokalnimi oblastmi in civilisti (Khol, 2006, str. 124). Kot ugotavlja Mustonen (2008, str. 21), definicija civilno-vojaškega sodelovanja v EU sicer odraža Natov koncept, je pa pogled EU širši in poudarja možnost uporabe različnih instrumentov, vojaških in civilnih, v operacijah kriznega menedžmenta.

Operacije kriznega menedžmenta EU razvijajo dve vrsti interakcij, ki spadajo v civilno-vojaško sodelovanje. Te operacije so vsaj deloma odvisne od civilnih institucij

\footnotetext{
${ }^{10}$ Evropska unija ne uporablja splošnega termina mirovne operacije, ampak govori o operacijah civilnega in vojaškega kriznega menedžmenta, pri čemer razumemo kot mirovne operacije tiste, ki se izvajajo v okviru skupne varnostne in obrambne politike (glej Garb in Ober, 2005, str. 97).
} 
in prebivalstva zaradi virov, informacij in tudi varnosti, poleg tega pa vojaške sile sodelujejo z drugimi mednarodnimi ali nevladnimi organizacijami. Civilno-vojaško sodelovanje je torej tako notranja vojaška podporna funkcija kot značilnost operacij kriznega menedžmenta EU, ki naj bi povečevala učinkovitost operacij (Khol, 2006, str. 124).

Ker se je EU odločila, da bo razvijala tako vojaške kot civilne zmogljivosti za krizni menedžment, je za notranje usklajevanje razvila koncept civilno-vojaškega usklajevanja (Civil-Military Co-ordination - CMCO). Svet EU je dokument o tem usklajevanju ${ }^{11}$ sprejel novembra 2003, pomen razvoja civilno-vojaškega usklajevanja pa se je znotraj evropske varnostne in obrambne politike poudarjal že od leta 1999. V splošnem je med civilno-vojaškim sodelovanjem in usklajevanjem mogoče potegniti ločnico, in sicer tako, da sodelovanje razumemo kot podporno funkcijo vojaški misiji (ki pokriva sodelovanje z zunanjimi akterji na taktični ali operativni ravni), usklajevanje pa je bilo izvirno oblikovano za notranje usklajevanje (ki pokriva načrtovanje, politično sprejemanje odločitev in implementacijo akcij EU v kriznem menedžmentu), lahko pa ga razumemo tudi kot pogoj za sodelovanje z zunanjimi akterji (po Mustonen, 2008, str. 21-22; Mazurkiewicz, 2014, str. 129-130).

Zamisel CMCO EU naj bi sicer bolj kot poudarjanje in razvijanje natančne strukture in postopkov vodila potreba po razvoju kulture usklajevanja, ki naj bi se vgrajevala v aktivnosti EU. Khol (2006, str. 127) ob tem ugotavlja, da snovanje skupnega modela civilno-vojaškega usklajevanja na ravni EU zapletajo različne nacionalne kulture civilno-vojaških razmerij držav članic EU. Poleg tega so še drugi dejavniki zapletanja. Mednje lahko štejemo različne institucionalne kulture vojakov in civilnega osebja, čeprav so zaradi skupne lokacije delovni stiki med vojaškim in civilnim osebjem v direktoratu generalnega sekretariata Sveta olajšani. Problematično je tudi nesorazmerje med vojaško in civilno sestavino, saj je civilnega osebja na sekretariatu že vseskozi precej manj. Kot ugotavlja Khol, je okvir kriznega menedžmenta EU oblikovala vojska, civilni prispevek pa je prišel pozneje in ni bistveno spremenil pristopa k strateškemu planiranju. Civilna stran tudi nima vstopa v verigo poveljevanja. Razlika med civilnim in vojaškim pristopom je vidna tudi v odnosu (bližini) do lokalnega prebivalstva. Vojska je usposobljena za najmanjši mogoči stik $\mathrm{z}$ njim in izolirana $\mathrm{v}$ vojaških bazah, medtem ko je civilno osebje EU $\mathrm{v}$ stalni interakciji z lokalnimi oblastmi in pomešano med lokalno prebivalstvo. Naslednja razlika med vojaki in civilisti v operacijah kriznega menedžmenta je $\mathrm{v}$ novačenju za operacijo. V vojskah večine držav EU je razmestitev v tujini razumljena kot običajna naloga za vojaka. Za delo v operacijah je torej vojake precej preprosto dobiti. Drugače je s civilnimi eksperti. Njihovo novačenje temelji praviloma na prostovoljni odločitvi posameznika, poleg tega je različne strokovnjake (zlasti na ozkih strokovnih področjih) iz domačih struktur zelo težko dobiti (običajno so v službah pri državnih ali lokalnih oblasteh) (po Khol, 2006, str. 127-128).

\footnotetext{
"I Civil-Military Coordination (CMCO), Council Document 14457/03, 7 November 2003 (Khol, 2006 opomba 11).
} 
Ko govorimo o sodelovanju vojske in civilnih akterjev na področju operacij kriznega menedžmenta v EU, moramo omeniti še civilno-vojaško celico (Civilian-Military Cell - CMC), ki je bila znotraj Vojaškega štaba EU ustanovljena decembra 2003. Med različnimi nalogami na področju strateškega planiranja je tudi planiranje skupnih civilno-vojaških operacij (Khol, 2006, str. 130-132; European Union Military Staff, 2009).

\section{SODELOVANJE VOJSKE IN HUMANITARNIH ORGANIZACIJ}

Besedno zvezo civilno-vojaško sodelovanje različni akterji uporabljajo v različnih kontekstih. Skupnost nevladnih organizacij uporablja izraz kot termin, ki se nanaša na vojaško vključevanje v humanitarno pomoč (Rehse, 2004, str. 13). Nevladne organizacije zavračajo vpletanje vojske v »humanitarni prostor«. Vidijo ga kot legitimizacijo intervencije s prizadevanjem za druge cilje ali za prikrivanje politične neuspešnosti. Verjamejo, da stapljanje vojaških in humanitarnih ciljev kompromitira humanitarne cilje in načela. Skupnost nevladnih organizacij neprestano opozarja, da vojske ne moremo jemati kot nevtralno in nepristransko, saj jo nadzoruje politika. Povezovanje nepristranskih humanitarnih akcij z vojaškimi cilji, ne glede na to, ali so stvarni ali le zaznani, vodi tudi k tveganju, da bodo humanitarni delavci zaznani kot sovražniki, s čimer bo ogrožena njihova osebna varnost. Mešanje mandatov naj bi tudi zmanjševalo uspešnost humanitarne pomoči ali celo onemogočalo nepristransko humanitarno delo. Zamisel, da bi bile humanitarne akcije podrejene vojski, je pri humanitarnih organizacijah povzročila hud odpor. Humanitarna skupnost vztraja pri tem, da mora razdeljevanje pomoči potekati po načelih nepristranskosti, nevtralnosti in neodvisnosti. Po drugi strani pa je vojska odkrila, da njena nova vloga v mirovnih operacijah zahteva učinkovito upravljanje za področje vojaško-humanitarnega prekrivanja (Rehse, 2004, str. 13-14).

Sodobne večdimenzionalne operacije v podporo miru se osredotočajo na civilno in humanitarno področje. Takšna širitev operacij lahko vodi do problematičnih odnosov ali celo do tekmovanja med vojsko in humanitarnimi organizacijami. Mednarodni odbor Rdečega križa (MORK) celo ugotavlja, da se zaradi zamegljene ločnice med vojaškim in humanitarnim delovanjem ruši koncept humanitarnega delovanja, ki je jedro mandata in aktivnosti odbora (Studer, 2001, str. 367).

Mednarodni odbor Rdečega križa je zaskrbljen, da bi humanitarna prizadevanja postala del političnega procesa in se tako politizirala. Politični proces naj bi sicer vodil v rešitev konflikta (pri tem je nujna tudi podpora vojaških sil), a humanitarne akcije so usmerjene v lajšanje trpljenja ljudi, ki nastaja zaradi krize. Humanitarno delovanje mora biti strogo ločeno od političnih ciljev mirovne operacije. Odbor zato zagovarja nevtralno in nepristransko humanitarno delovanje sredi konflikta (po Studer, 2001, str. 368, 372). Nasprotuje tudi neposrednemu vključevanju vojske v humanitarne aktivnosti, saj se želi izogniti lokalnemu razumevanju, da so humanitarne akcije povezane s političnimi in vojaškimi cilji, zato zahteva zelo jasno razločevanje med operacijami v podporo miru in humanitarnimi aktivnostmi (Rehse, 
2004, str. 41). Usmerjevalni odbor za humanitarni odziv (Steering Committee for Humanitarian Response - SCHR), ki je koalicija devetih največjih mednarodnih humanitarnih organizacij (član je tudi Mednarodni odbor Rdečega križa), je vojaško izvajanje humanitarne pomoči sicer ločil na izvajanje v »normalnih okoliščinah« in V »izjemnih okoliščinah«. V »normalnih okoliščinah«, ko humanitarne organizacije ustrezno opravljajo svoje delo, za vojsko ni primerno, da izvaja akcije na humanitarnem področju ${ }^{12}$ (Rehse, 2004, str. 41-42).

Zakaj vojska želi biti povezana s humanitarnim delovanjem? Vojska verjame, da so za uspeh vojaške operacije bistveni tudi dobri odnosi z lokalnim prebivalstvom. Humanitarno delo sicer ni glavna naloga vojske, se pa gleda nanj kot na pomožno nalogo v okviru doseganja cilja sprejemljivosti misije. Drugo, bolj razširjeno mnenje v vojski je, da lokalno prebivalstvo pričakuje, ne glede na mandat, da bodo »mirovniki« pomagali pri skrbi za njihove potrebe, še zlasti, kadar humanitarne organizacije same ne obvladujejo razmer. Nekatere vlade pa s humanitarno dejavnostjo svojih vojsk v mirovnih operacijah (in zlasti z opozarjanjem na humanitarni značaj dejavnosti) tudi želijo izboljšati domačo podobo vključenosti v operacije (Studer, 2001, str. 378-379).

Humanitarno delo vojske, ki se je posebno razmahnilo po neuspehih mirovnih operacij v Mogadišu, Kigaliju in Srebrenici (zato se je namreč zmanjšala politična volja po mandatih, ki bi bili usmerjeni v preprečevanje konfliktov, raje se je tvegalo z mešanjem humanitarnih in političnih mandatov ter vlog; politično in vojaško delovanje se zamenja s humanitarnim), prinaša s seboj dve vrsti nevarnosti. Prva je, da se lahko zgodi, da so mednarodne vojaške sile videne kot stran v konfliktu, zato je v trenutku, ko misija od njih zahteva uporabo sile, njihovo humanitarno delovanje kompromitirano. Obstaja pa tudi skušnjava, da humanitarna pomoč postane odvisna od privolitve strani v sporu, pri čemer bi politična telesa postavljala politične pogoje. Druga nevarnost je, da humanitarno delovanje vojsko lahko odvrača od njenega glavnega cilja. Vojaki so tako uporabljeni za »zdravljenje simptomov in ne bolezni«. Mednarodni odbor Rdečega križa je še zlasti zaskrbljen zaradi nevarnosti, da V očeh vojskujočih se strani oslabi koncept nepristranskega humanitarnega delovanja. Ne zavrača humanitarnega delovanja vojske kot takšnega, ampak ga bolj skrbi škodljiv učinek na civilno humanitarno delovanje, na slabšanje podobe civilnih humanitarnih delavcev (skrb, da se ta podoba ne bi spremenila iz podobe $»$ nedolžnih opazovalcev« v podobo potencialnih strani v konfliktu). V pokonfliktnih razmerah sicer humanitarna vloga vojske ni tako vprašljiva kot v konfliktnih, čeprav nekaj nevarnosti zaradi prepletanja humanitarnega in vojaškega delovanja ostaja, zlasti ob obnovitvi sovražnosti (Studer, 2001, str. 373-375).

\footnotetext{
12 Zlasti se ugovor nanaša na projekte stila hitrega vpliva (Qiuck Impact Projects - QIPs), ki so namenjeni mednarodni publiciteti in psihološkim razlogom, da se ohranja javna podpora misiji in izboljšuje morala osebja. SCHR trdi, da ti projekti služijo izboljševanju uspeha vojaške misije in nanje ne moremo gledati kot na humanitarne (Rehse, 2004, 42). QIPs sicer pozna tudi OZN, in sicer jih definira kot majhne, hitro izvršljive projekte, ki so v korist prebivalstvu. Voperacijah OZN se uporabljajo za ustanavljanje in graditev zaupanja $v$ misijo, njen mandat in mirovni proces, torej izboljšujejo okolje za učinkovito uveljavljanje mandata (DPKO Policy Directive, 12. februar 2007).
} 
Studer (2001, str. 375-376) opozarja tudi na razpravo, v kateri se pojavljata dva argumenta proti humanitarnemu delovanju vojske. Vojska naj bi namreč največ prispevala $\mathrm{k}$ humanitarnemu delovanju ravno s tem, da skrbi za red in varnost. Zgolj humanitarna misija ne bi nikoli smela biti razlog za namestitev vojaških enot, niti ne bi smela služiti kot »figov list« za prikrivanje politične nedejavnosti. In drugič, upoštevati je treba, da ima humanitarna pomoč tako pozitivne kot negativne posledice. Po eni strani pripomore k ustvarjanju razmer za reševanje konflikta, po drugi pa lahko konflikt tudi podaljšuje.

O delovanju vojske v mirovnih operacijah je na politično-odločevalski ravni (vsaj bilo) jasno, da je primarna vloga vojske vojaška, se pa v zadnjem času pojavlja težnja po politiki neposrednega vključevanja vojske $\mathrm{v}$ civilne in humanitarne naloge. $\mathrm{Na}$ operativni ravni se skušajo vojaške in humanitarne organizacije bolj povezati, zlasti v obliki aktivne vojaške podpore humanitarnemu delu. Za humanitarne organizacije je pravi izziv, da jasno ločijo humanitarno delovanje od vojaškega, pri tem pa ohranijo prednosti sodelovanja z vojsko (Studer, 2001, str. 376-377).

Mednarodni odbor Rdečega križa zavrača termin CIMIC (civil-military cooperation) za opisovanje svojega odnosa z vojsko, saj CIMIC zlasti vidi kot vojaško funkcijo. Nevarnost civilno-vojaškega sodelovanja je $\mathrm{v}$ tem, da lahko privede vojsko do tega, da gre prek svojega (vojaškega) mandata in se osredotoči bolj na humanitarne aktivnosti kot na naloge miru in varnosti (Studer, 2001, str. 378).

Mednarodni odbor Rdečega križa se torej nekako upira tesnemu usklajevanju svojih aktivnosti $\mathrm{z}$ aktivnostmi vojske. Razlogi so $\mathrm{v}$ njegovem posebnem mandatu, $\mathrm{v}$ načelih in »kulturi«. Eden izmed argumentov proti sodelovanju in usklajevanju je mogoče strniti v stavek: »vojska lahko postane del problema in ne rešitve«. Težava lahko nastane, če vojska ne spoštuje dovolj mednarodnega humanitarnega prava (primer v Somaliji leta 1992). Drugi pogosto uporabljani argument odbora proti sodelovanju z vojsko v mirovnih operacijah pa je, da bi vojska lahko potrebovala odbor kot nevtralnega posrednika (primer v Somaliji, ko je obiskal osebe, ki jih je priprl UNOSOM II ${ }^{13}$, in Aididove zapornike; primer Kosova, ko je Mednarodni odbor Rdečega križa obiskal osebe, ki jih je priprl Kfor). Nekaj težav povzročata tudi zbiranje in delitev informacij. Vprašanje namreč je, ali bi imel odbor koristi od informacij, ki bi jih dobil od vojske, pa tudi, kakšne informacije naj bi dajal vojski. Zavezan je namreč zaupnosti, kar je omejevalni dejavnik pri zagotavljanju informacij. Studer (2001, str. 381) sicer ugotavlja, da vojska načeloma razume in sprejema to zaupnost.

Nadalje je nekoliko vprašljivo tudi zagotavljanje vojaškega spremstva humanitarnim agencijam. Humanitarna skupnost sicer o tem nima enotnega stališča. Stališče Mednarodnega odbora Rdečega križa je, da ne uporabljajo oboroženega spremstva niti zaščite vojakov OZN. Meni namreč, da bi povezava s komerkoli oboroženim

${ }^{13}$ UNOSOM II je bila operacija OZN v Somaliji v letih 1993-1995. 
lahko bolj ogrozila kot varovala njegovo osebje. Drugače je z opremo, ki jo redno hranijo in varujejo mirovne sile. Po mnenju odbora takšna zaščita lastnine proti banditstvu in drobnemu kriminalu ne more ogroziti njegove podobe kot nevtralne in nepristranske institucije.

Kaj pa uporaba vojaških zmogljivosti za humanitarno delovanje? V 80. in 90. letih prejšnjega stoletja so se vojaške zmogljivosti v humanitarnih operacijah veliko uporabljale (npr. zračni most v Etiopiji leta 1985 in 1988 ipd.). V zadnjem času je Mednarodni odbor Rdečega križa pri uporabi vojaških zmogljivosti pazljivejši (povsem zavrača je sicer ne), saj vojska uporablja svoje zmogljivosti za različne naloge, med katerimi so tudi takšne, ki bi odbor lahko kompromitirale.

Pogosto se izkaže, da je glavna ovira učinkovitemu sodelovanju humanitarnih organizacij in vojske kulturna neskladnost (na primer humanitarnost vojske, sodelovanje humanitarnih delavcev $\mathrm{v}$ vojaških aktivnostih težje predstavljivo; vojaška linija poveljevanja, pravila in operativni ukazi pri vojski, neodvisnost mišljenja in precej odločanja neposredno na terenu pri humanitarnih delavcih). Pred skupnim delovanjem je nujno, da vojska dobi vpogled v načine dela humanitarnih delavcev in da se ti seznanijo z vojaškimi pristopi. Spoznati in spoštovati morajo tudi mandate drug drugega, da se izognejo nesporazumom. Usposabljanje pomaga dosegati skupno znanje in povečuje predvidljivost (povzeto po Studer, 2001, str. 380-384).

Za konec še zanimive ugotovitve iz empirične raziskave Mojce Pešec o sodelovanju akterjev znotraj Natovega celovitega pristopa v operacijah. Na vprašanja v raziskavi so odgovarjali izbrani predstavniki civilnih in vojaških organizacij, predvsem z izkušnjami iz Afganistana (več v Pešec, 2015, str. 190). V raziskavi je avtorica anketiranim med drugim postavila tudi vprašanje, če so njihove matične organizacije (Nato, OZN, UNICEF, CCOE, Mednarodna organizacija za migracije, Norveški svet za begunce itn.) izvedle strukturne ali procesne spremembe, ki bi izboljšale sodelovanje s civilnimi oziroma vojaškimi akterji v kompleksnih krizah. Odgovori na to vprašanje so potrdili, da si vladne organizacije in Nato prizadevajo, da bi $\mathrm{v}$ kompleksnih krizah vzpostavili boljše sodelovanje med vojaškimi in civilnimi akterji, pri tem pa upoštevajo operativne usmeritve OZN. Vlade in Nato so za boljše sodelovanje razvili nekatere zmogljivosti, medtem ko nevladne organizacije in posamezne agencije OZN v posameznih situacijah pristajajo na usklajevanje aktivnosti, skupno delovanje pa večinoma zavračajo. V zaostrenih varnostnih razmerah so nekatere izmed njih na sodelovanje $\mathrm{z}$ vojaškimi akterji pripravljene, druge pa se od njih povsem umaknejo. Odgovori anketiranih iz različnih organizacij na vprašanje o optimalnih oblikah sodelovanja so precej različni, vsi pa vidijo možnosti v medsebojni izmenjavi informacij (Pešec, 2015, str. 208-212). 
Sklepne Pregled vsebine in uporabe termina civilno-vojaško sodelovanje, najpogosteje ugotovitve poznanega pod kratico CIMIC, pokaže, da v okviru sodobnih mirovnih operacij tako v vsebini kot uporabi tega termina ni enotnosti. Pa ne samo to, srečamo celo nasprotovanje sodelovanju na terenu, kar vidimo zlasti v razmerju med humanitarnimi organizacijami in vojaškimi silami.

Vsekakor pa lahko ugotovimo, da sodobne mirovne operacije, ki jih označujeta večdimenzionalnost (koncept Organizacije združenih narodov) in celovitost (koncept Nata) v pristopih in kompleksnost v akterjih, potrebujejo sodelovanje in tudi usklajevanje teh akterjev pri opravljanju njihovih dejavnosti. Za opisovanje procesov vzpostavljanja tega odnosa se je v mednarodni skupnosti najprej začel razvijati termin civilno-vojaško sodelovanje, ki ga je kmalu za eno svojih doktrin delovanja v mirovnih operacijah privzel Nato, pozneje pa še EU, predvsem za tisti del aktivnosti, ki se nanašajo na podporo vojski. Danes zato CIMIC povezujemo predvsem z eno izmed funkcij vojske v Natovih operacijah (tako na ozemlju operacij kot doma) in vojaških operacijah Evropske unije, preostali akterji pa so začeli uporabljati nove termine in kratice, pri čemer je večjo vlogo dobilo usklajevanje namesto sodelovanja.

Potreba po sodelovanju in usklajevanju vojaškega in civilnih akterjev se je pokazala zlasti po razvoju razmer (in operacij) v Bosni in Hercegovini od leta 1995 ter se nasploh stopnjevala $\mathrm{z}$ večanjem števila civilnih akterjev v mednarodnih operacijah in na misijah.

Še bolj kot sodelovanje med vojsko in civilnimi agencijami različni akterji poudarjajo pomen koordinacije (usklajevanja) med vojsko in drugimi akterji. Nekatere opredelitve civilno-vojaškega sodelovanja (na primer Natova) vsebujejo tako sodelovanje kot usklajevanje. Druge (na primer OZN) se bolj osredotočajo na usklajevanje. Ena izmed razlag pravi, da gre pri uporabi različnih pojmov za to, da OZN razume sodelovanje le kot najmočnejši odnos med sestavinami misije, kot so vojaška, civilna in policijska

S pojmom usklajevanje pa želi pokazati, da se lahko razvijejo tudi manj trdne oblike sodelovanja, včasih zgolj koeksistenca. Pojem usklajevanje naj bi tako pomenil le lestvico, na kateri se razvijejo različni odnosi med omenjenimi akterji (glej Coning in Holshek, 2012, 28-29).

Deloma se kaže nezdružljivost delovanja humanitarnih organizacij z delovanjem aparata mirovnih operacij, zlasti z vojsko. Ob tem humanitarne organizacije izražajo strah pred politizacijo njihovega delovanja in večjo ogroženostjo, če bi se njihovo delovanje prepletalo z delovanjem (čeprav humanitarnim) vojaških mirovnih sil. Humanitarno delovanje vojske naj bi bila le podporna funkcija vojaškemu delovanju v mirovnih operacijah, ki je še vedno temeljno. Kot ugotavlja Ritjens (2006, str. 6), sta (torej) pri civilno-vojaškem sodelovanju razvidni tako njegova politična kot humanitarna identiteta. 


\section{Literatura}

1. AJP-3.4.9. Allied Joint Doctrine for Civil-Military Cooperation. February 2013.

2. AJP-9. NATO Civil-military Co-operation (CIMIC) Doctrine. June 2003.

3. Ankersen, C. (ed)., 2007. Civil-military Cooperation in Post-conflict Operations: Emerging theory and practice. Cass Military Studies.

4. CIMIC Centre of Excellence. Dostopno na http://www.cimic-coe.org/, 25. 3. 2016

5. Coning, C., 2007. Civil-Military Coordination Practices and Approaches within United Nations Peace Operations. Journal of Military and Strategic Studies. Fall, Vol.10, Issue 1.

6. Coning, C., Holshek, C., 2012. United Nations Civil-Military Coordination (UN-CIMIC). Williamsburg, USA: Peace Operations Training Institute.

7. DPKO Policy Directive, 12 February 2007. Quick Impact Projects (QIPS). United Nations Department of Peacekeeping Operations.

8. European Union Military Staff. Brochure. February 2009. Dostopno na: www.consilium. europa.eu/eums, 14. 5. 2009.

9. Garb, M., in Ober, K., 2005. Mirovne operacije Zahodnoevropske in Evropske unije. V: Jelušič, L., (ur.): Mirovne operacije in vloga Slovenije. Ljubljana: Fakulteta za družbene vede, str. 97-109.

10. Gebhard, C., 2008. Civil-Military Coordination and Cooperation in the Context of the EU's Crisis Management: CMCO versus CIMIC. Conceptual and Terminological Clarifications Second version. Info Aktuell 01/2008. National Defence Academy, Institute for Peace Support and Conflict management.

11. Henriksson, K. (ed.), 2008. CMC Finland Yearbook 2008. CMC Finland Civilian Crisis Management Studies, Volume 1, Number 6/2008.

12. Khol, R., 2006. Civil-Military Co-ordination in EU crisis management. V: Agnieszka Nowak (ed): Civilian Crisis management: the EU way. Chaillot Paper, No. 90, June 2006.

13. Logar Kelc, M., 2007. Civilno-vojaško sodelovanje. Diplomsko delo. Fakulteta za družbene vede, Ljubljana.

14. M2 Presswire. Nov. 16, 2007. Norwegian Government: Multidimensional and Integrated Peace Operations: Trendsand Challenges. Coventry.

15. Mazurkiewicz, A., 2014. NATO and EU approach towards civil-military relations in military operations. Polityka i Spoleczeństwo, 2(12), str. 125-140.

16. MC 411/1. NATO Military Policy on Civil-Military Co-operation. NATO International Military Staff, 2002.

17. Multinational Cimic Group. Dostopno na http://www.cimicgroup.org/, 25. 3. 2016.

18. Mustonen, J., 2008. Coordination and Cooperation on Tactical and Operational levels. Stdying EU-ESDP Crisis management Instruments in Bosnia and Herzegovina. $V$ : Henriksson, Kirsi (ed.): CMC Finland Yearbook 2008. CMC Finland Civilian Crisis Management Studies, Volume 1, Number 6/2008, str. 1-41.

19. NATO - SHAPE - Civil Military Cooperation (CIMIC). Dostopno na: http://nato.int/ shape/community/pio/contact_cimic.htm, 16. 3. 2009.

20. Pě̌ec, M., 2015. NATO in celovit pristop pri reševanju kompleksnih kriz. Doktorska disertacija. Ljubljana: FDV.

21. Ramsbotham, O., Woodhouse, T., 1999. Encyclopedia of international Peacekeeping Operations. Santa Barbara: ABC-CLIO.

22. Rehse, P., 2004. CIMIC: Concepts, Definitions and Practice. IFSH Heft 136. IFSH Hamburg, junij, 2004.

23. Ritjens, S. J. H., 2006. Civil-military cooperation in response to a complex emergency: just another drill? Dissertation. University of Twente, the Netherlands.

24. SHAPE News Release, 05 May 2009: The Multinational Civil-military Cooperation (CIMIC) Group HQ is officially established. Dostopno na http://www.nato.int/shape/ news/2009/05/090505a.html, 15. 05. 2009. 
25. Studer, M., 2001. The ICRC and civil-military relations in armed conflict. International Review of the Red Cross, Vol. 83, No. 842, str. 367-391.

26. UN-CMCoord Field Handbook (v1.0). 2015. Geneva: United Nations.

27. Zandee, D., 1999. Civil-military interaction in peace operations. NATO Review, Vol. 47, No. 1, Spring, str. 11-15. Webedition. 